\title{
Effects of Endothelin-A Receptor Antagonist BQ-123 on Plasma Leptin Levels Streptozotocin Induced Diabetic Rats \\ A Ozturk ${ }^{1}$, H Erdogan $^{2}$, F Ekici $^{3}$, D Aydin ${ }^{4}$, E Sogut $^{5}$
}

\begin{abstract}
Objectives: Leptin and Endothelin (ET) as important endogenous factors interact with each other which may contribute to a better understanding their role in diabetic pathogenesis.

We aimed to evaluate the relationship between Leptin and ET by investigating the influence of BQ-123, an ET-A receptor $\left(\mathrm{ET}_{\mathrm{A}} \mathrm{R}\right)$ antagonist, on Leptin levels in rats with diabetes induced by Streptozotocin (STZ).

Methods: In this study, 24 male Wistar-albino rats were divided into three groups; Control, STZ, STZ+BQ-123 groups. Experimental diabetes was induced by delivering a single dose of $60 \mathrm{mg} / \mathrm{kg}$ intravenous STZ. The rats in the STZ+BQ-123 group received $4 \mathrm{mg} / \mathrm{kg}$ i.v.in total BQ-123 $(2 \mathrm{mg} / \mathrm{kg}+2$ $\mathrm{mg} / \mathrm{kg}$ on the 39th and 40th days). The plasma specimens collected 6 hours after the last BQ-123 delivery were studied for biochemical parameters.
\end{abstract}

Results: At the end of the experiment, the weights of rats in the STZ and STZ+BQ-123 groups were significantly lower compared with the values in the Control group. The levels of blood glucose were significantly higher in the STZ and STZ+BQ-123 groups than in the Control group. While rats with STZinduced diabetes demonstrated no changes in Leptin, $\mathrm{PC}$ and $\mathrm{K}^{+}$levels, they exhibited reduced $\mathrm{NO}, \mathrm{Na}^{+}$ and $\mathrm{Cl}^{-}$concentrations. The levels of plasma TBARS was significantly higher in the STZ group than in the Control and STZ+BQ-123 groups.

Conclusion: Although the levels of plasma Leptin was no statistically significant difference between the groups, BQ-123 groups lead to further decrease in reduced levels of Leptin than only diabetic group. Our findings have been considered that $\mathrm{ET}_{\mathrm{A}} \mathrm{R}$ antagonists have positive impacts depending on the dosage in the diabetic rats.

Key words: Endothelin-1, experimental diabetes, Leptin, BQ-123

From: ${ }^{1}$ School of Health, Kastamonu University, Kastamonu, ${ }^{2}$ Department of Physiology, Faculty of Medicine, Namik Kemal University, ${ }^{3}$ Department of Physiology, Faculty of Medicine, Yildirim Beyazit University, ${ }^{4}$ Department of Physiology, Faculty of Medicine, Turgut Özal University, Ankara, Turkey and ${ }^{5}$ Department of Biochemistry, Faculty of Medicine, İzmir Kâtip Çelebi University, İzmir, Turkey.

Correspondence: Dr H Erdogan, Department of Physiology, Medical Faculty of Namik Kemal University TR-59100, Tekirdag, Turkey. Fax: +90 282250 9928, email: haserdogan@yahoo.com 


\section{INTRODUCTION}

Diabetes Mellitus (DM) is the most common endocrine and metabolic disorder of our age, emerging as a result of real or functional lack of insulin, which is characterized by blood, carbohydrate, protein and fat metabolism disorder (1-3).

Today, experimental diabetes models can be formed with various materials and methods. One of the ingredients used to create an experimental diabetes model is streptozotocin (STZ). Diabetes created with STZ is a commonly used model in terms of formation of insulin dependent diabetes model of human (4).

ET's are the peptides occurring naturally in many cell types of the body and known as the most potent vasoconstrictor molecules $(5,6)$. There are ET isopeptides in humans and other mammals, named as ET-1, ET-2 and ET-3 which have different structural and pharmacological effects. ET-1 is the primarily ET which is synthesized by endothelial cells (7). It shows paracrine and autocrine effects via $\mathrm{ET}_{\mathrm{A}} \mathrm{R}$ and $\mathrm{ET}_{\mathrm{B}} \mathrm{R}$ on the endothelial and smooth muscle cells (8). There are many studies that have demonstrated the increase in the level of ET-1 in diabetes $(9,10)$. ET-1 also leads to the progression of DM (11).

Leptin is a protein hormone, that derives its name from the Greek word leptos, which means thin, produced by ob-gene in fat cells and other tissues and released to plasma $(12,13)$. Insulin is the most researched Leptin-associated hormone and an important regulator of the ob-gene expression (14). Leptin and other adipocytokines were associated with the type 2 DM and insulin resistance (15). It has been demonstrated that Leptin deficiency lead to severe insulin resistance in uncontrolled DM (16). Additionally, it has been informed that Leptin had an anti-diabetic effect in diabetic rats. Researches has been shown that Leptin had powerful anti-diabetic effect in the STZ- induced insulin dependent diabetic rats and transgenetic mice (17). 
There are some studies evaluating the relationship between Leptin and ET-1 in different diseases and systems. For example, ET-1 stimulates Leptin production with $\mathrm{ET}_{\mathrm{A}} \mathrm{R}$ in adipocyte cultures (18). In another study conducted by Juan et al., Leptin increased the levels of $\mathrm{ET}_{\mathrm{A}} \mathrm{R}$ in vascular smooth muscle cells (19). It has been informed that, Leptin induced ET-1 in endothelial cells (20). These data suggest that increased ET-1 levels in diabetes due to the relationship between Leptin and ET-1, may affect the plasma Leptin levels.

Although there are many studies evaluating as well as Leptin and ET-1 separately in various diseases and systems, any study that demonstrates how ET-1 and Leptin affect each other in diabetes and how ET receptor antagonists affect plasma Leptin levels in diabetes, could not find. Therefore, we aimed to investigate the effects of $\mathrm{ET}_{\mathrm{A}} \mathrm{R}$ antagonist BQ-123 on Leptin levels in STZ-diabetic rats.

The studies demonstrate that a decrease in Leptin levels may occur in STZ-induced diabetic rats. How this decrease affects in diabetic rats given $\mathrm{ET}_{\mathrm{A}} \mathrm{R}$ antagonist $\mathrm{BQ}-123$ became our scientific curiosity. Because, there are some studies demonstrating increase in ET-1 and endothelium caused up-regulation of Leptin secretion levels in diabetes.

Hence, Leptin levels which were already decreased in diabetes may be reduced more with the application of ET receptor antagonist. It is known that, decrease in Leptin levels in diabetes caused adverse effects. So, it should be determined that how $\mathrm{ET}_{\mathrm{A}} \mathrm{R}$ antagonist affected the increased levels of Leptin in diabetes.

\section{SUBJECTS AND METHODS}

Before the experiment, the approval was taken from Gaziosmanpasa University Local Ethics Committee for Animal Experiments and animal rights were protected (2010-HADYEK-029). In the experiment, 24 male Wistar albino rats weighting 180-250 g were used. Rats were kept 
in cages at room temperature $21 \pm 2{ }^{\circ} \mathrm{C}$ with a $12 \mathrm{~h}$ light/dark cycle, fed with standard rat pellet food and tap water.

\section{Chemicals}

STZ and BQ-123 were obtained from Sigma Chemical Co., (St. Louis, MO). STZ was dissolved in cold phosphate-citrate buffer solution $(0.1 \mathrm{M}, \mathrm{pH}=4.5)$. Buffer solution was prepared freshly and protected from light. BQ-123 dissolved in $0.9 \% \mathrm{NaCl}$.

\section{Procedure for diabetes}

Rats were randomly divided into 3 groups and each group included 8 rats (Control group, $\mathrm{n}=8$, STZ group $\mathrm{n}=8$, STZ+BQ-123 group $\mathrm{n}=8$ ). Blood-glucose levels of the each rat, fasted for $12 \mathrm{~h}$, were measured with a sugar measuring instrument (glucometer) (PlusMED ACCURO pM1300) and recorded. After that, by measuring the weight of each rats, STZ 60 $\mathrm{mg} / \mathrm{kg}$, which was prepared freshly by dissolving in phosphate-citrate buffer $(\mathrm{pH}=4.5)$, was administered i.p. to the rats in STZ and STZ+BQ-123 groups. For the control group, phosphate-citrate buffer with the same volume was administered i.p. Then, the feeding of rats was released. Fasting blood glucose levels were measured again $72 \mathrm{~h}$ after the STZ administration, the rats with the level of $200 \mathrm{mg} / \mathrm{dl}$ or higher were considered as diabetic. In order to complete the formation of diabetic physiopathology, rats were kept under the appropriate conditions for 40 days after the STZ implementation. The diabetes procedure was prepared with the reference of few studies that have been done before $(21,22)$.

\section{Treatment procedure}

The rats in STZ+BQ-123, STZ group, 39th and 40th days after the application, (2 $\mathrm{mg} / \mathrm{kg}+2 \mathrm{mg} / \mathrm{kg}$ ), a total of $4 \mathrm{mg} / \mathrm{kgBQ}-123$ was administered i.v. from tail vein. For the rats in control and STZ group, instead of BQ-123, same volume of saline was given. Rats were 
sacrificed by taking 4-5 $\mathrm{ml}$ cardiac blood samples under anesthesia with, Ketamine (30 $\mathrm{mg} / \mathrm{kg})$ and xylazine $(5 \mathrm{mg} / \mathrm{kg}) 6$ hours after the last BQ-123 implementation.

\section{The Measurement of plasma leptin}

Leptin levels were measured in the plasma obtained after centrifugation of blood by using the method of Enzyme-Linked Immunosorbent Assay (ELISA). The Mouse / Rat ELISA Leptin kit (Biovendor, Cat no: RD291001200R, North Carolina, USA) was used for determination of rats' leptin levels by ELISA device (Organ tecnicareade $230 \mathrm{~S}$ ). The results were read at 450 $\mathrm{nm}$ with the help of spectrophotometer (GBC Cintra 10e) and calculated as ng/ml. Leptin ELISA kit is based on the sandwich principle. Microtiter layer is covered with monoclonal antibody which is sensitive against a single antigenic portion of Leptin molecule. Patient samples containing large molecules of Leptin were incubated in 'rabbit anti-Leptin' antibodycoated layer and the sandwich complex was formed. After incubation, unbound material is washed and in order to determine the bound Leptin, 'anti rabbit' peroxidase is added. Substrate solution is added, forming color intensity is directly proportional to the amount of Leptin in patient serum (23).

\section{Measurement of serum TBARS levels}

Serum TBARS levels were measured by Mihara and Uchiyama method. In this, in TBA test reaction, malondialdehyde (MDA) or MDA-like substances produce a pink color by entering reaction with TBA and give the maximum absorbance at $532 \mathrm{~nm}$. The reaction was carried out at $90{ }^{\circ} \mathrm{C}$ and at $\mathrm{pH}=2-3$ for $15 \mathrm{~min}$. In order to bring down the proteins, the samples were stirred with two-fold volume of $10 \%$ cold trichloroacetic acid (w/v). The particles were brought down by centrifugation and the reaction of liquid part of the supernatant and equal volume of $0.67 \%$ of (w/v) TBA was performed in boiling water bath for 10 minutes. After 
cooling, it was read with the spectrophotometer at $532 \mathrm{~nm}$. The results were calculated as $\mathrm{nmol} / \mathrm{ml}(24)$.

\section{Measurement of the level of serum PC}

Detection of protein carbonyl groups; was performed on the basis of the spectrophotometrically measurement of stable hydrazone compounds formed as a results of reaction of protein carbonyl groups with 2,4-dinitrophenyl hydrazine at $370 \mathrm{~nm}$. During calculations, $\mathcal{E}=22000 \mathrm{M}-1 \mathrm{~cm}-1$ was accepted as molar absorption coefficient at $370 \mathrm{~nm}$ for 2.4 dinitrophenyl hydrazine. Protein carbonyl levels were calculated as $\mathrm{nmol} / \mathrm{ml}(25)$.

\section{Measurement of serum NO Level}

Amount of nitrite in the serum was determined by the Griess reaction after deproteinization. Total nitrite (nitrite + nitrate) was evaluated with the modified cadmium reduction method. Nitrate reduction was provided at the end of the 90-minute incubation with copper $(\mathrm{Cu})$ coated cadmium granules deproteinized sample supernatant in $\mathrm{pH} 9.7$ glycine buffer. Produced nitrites; were determined with sulfanilamide and related N-naphtylethylenediamine (NNDA) diazotization. A pink color occurred as a result of the reaction was read with the help of spectrophotometer at a wavelength of $545 \mathrm{~nm}$. Nitrate concentration was determined by substracting the resulting concentration from the first concentration (26).

\section{Other biochemical analyses}

Plasma $\mathrm{Na}, \mathrm{K}, \mathrm{Cl}$ values were measured with the help of an auto analyzer (Cobas C 501, Tokyo, JAPAN) by using indirect $\mathrm{Na}^{+}, \mathrm{K}^{+}, \mathrm{Cl}^{-}$kits.

\section{Statistical analysis}

Statistical analysis was performed with "SPSS 19.0 for Windows". For the comparison of the differences between the groups, "One-way ANOVA" test was used. In which case the data did 
not comply with the normal distribution ( $p \leq 0.05$ according to the Levene test), instead of this test, "Kruskal-Wallis Analysis of Variance" was applied. When the differences between groups were found significant in one-way analysis of variance $(p \leq 0.05)$, the groups were compared in pairs with "Tukey HSD" which is one of the Post Hoc tests. When the differences between groups were found significant in Kruskal-Wallis Analysis of Variance $(p \leq 0.05)$, the groups were compared in pairs with "Mann-Whitney U test (Bonferroni correction)". Results were expressed as mean \pm standard deviation.

\section{RESULTS}

\section{Live Body Weights of Rats during the Test}

The weights of the rats were measured at the beginning, in the middle and at the end of the experiment, they were recorded as; for the control group; $184.37 \pm 12.37,193.13 \pm 11.63,239.38$ $\pm 15.68 \mathrm{~g}$ and for STZ group; $208.13 \pm 7.53,200.00 \pm 10.35,191.25 \pm 11.57 \mathrm{~g}$; for STZ + BQ123 group, $231.25 \pm 25.03,218.75 \pm 18.47,203.50 \pm 29.90 \mathrm{~g}$. The weights were compared at the end of the experiment between the groups, the weights of rats in STZ group $(p=0.0001)$ and STZ + BQ-123 group ( $p=0.015)$ were significantly lower than the control group. Diabetic rats lost weight.

\section{Fasting Blood Glucose Levels in Rats during the Test}

The fasting blood-glucose levels of the rats compared on the basis of the groups, no significant difference was found between the groups at the beginning of the experiment $(p=0.384)$. In the measurements performed 72 hours after the application of STZ, the blood glucose levels of rats in control, STZ and STZ+BQ-123 groups were recorded as $127.00 \pm 15.32,491.75 \pm 72.65,501.13 \pm 75.75 \mathrm{mg} / \mathrm{dl}$, respectively. The blood glucose levels of the rats in STZ and STZ + BQ-123 groups were found significantly higher than the levels 
of the control group (for both $p=0.0001$ ). An experimental diabetes model was achieved in rats with STZ.

\section{Plasma Levels of Leptin, Serum Levels of PC, TBARS, NO}

The plasma Leptin levels of the rats in the experimental groups were, in the control $0.92 \pm$ $0.58 \mathrm{ng} / \mathrm{ml}$, in STZ group; $0.58 \pm 0.34 \mathrm{ng} / \mathrm{ml}, \mathrm{STZ}+\mathrm{BQ}-123$ group; $0.38 \pm 0.29 \mathrm{ng} / \mathrm{ml}$. Leptin levels were analyzed according to the groups, but no significant difference was found $(p=0.055)($ Table $1 ;$ Figure 1$)$.

TBARS levels of rats in experimental groups in the control, STZ and STZ+BQ-123 groups were found as $1.55 \pm 0.16 \mathrm{nmol} / \mathrm{ml}, 1.97 \pm 0.24 \mathrm{nmol} / \mathrm{ml}, 1.65 \pm 0.10 \mathrm{nmol} / \mathrm{ml}$, respectively. TBARS values of the STZ group were significantly higher than the control $(p=0.0001)$ and STZ+BQ-123 groups $(\mathrm{p}=0.0004)$, (Table 1; Figure 2).

PC levels of rats in experimental groups in the control, STZ and STZ+BQ-123 groups were found as $903.88 \pm 280.45 \mathrm{nmol} / \mathrm{ml}, 930.50 \pm 252.09 \mathrm{nmol} / \mathrm{ml}, 1040.50 \pm 400.41 \mathrm{nmol} / \mathrm{ml}$, respectively. PC levels were analyzed according to the groups, there was no statistically significant difference between the groups $(p=0.665)$, (Table 1; Figure 3 ).

NO levels of rats in experimental groups in the control, STZ and STZ+BQ-123 groups were measured as $46.32 \pm 3.85 \mathrm{nmol} / \mathrm{ml}, \quad 38.52 \pm 2.26 \mathrm{nmol} / \mathrm{ml}, 37.48 \pm 4.88 \mathrm{nmol} / \mathrm{ml}$, respectively. NO levels of STZ $(p=0.0001)$ and STZ+BQ-123 ( $\mathrm{p}=0.0001)$ groups were statistically significant lower than the values of the control group (Table 1; Figure 4).

\section{Other biochemical parameters}

The serum $\mathrm{Na}^{+}$concentration levels were measured in control, STZ and STZ+BQ-123 were $137.75 \pm 3,01 \mathrm{mmol} / \mathrm{L}, 126.75 \pm 7.57 \mathrm{mmol} / \mathrm{L}, 128.50 \pm 12.34 \mathrm{mmol} / \mathrm{L}$, respectively Serum $\mathrm{Na}^{+}$ concentration values of STZ group, were significantly lower than the values of the control group ( $p=0.001$ ). There was no significant difference between the other groups. 
Serum $\mathrm{K}^{+}$concentrations values were measured in the control, STZ and STZ + BQ-123 groups as $5.45 \pm 0.64 \mathrm{mmol} / \mathrm{L}, 6.03 \pm 1.99 \mathrm{mmol} / \mathrm{L}$ and $5.08 \pm 0.97 \mathrm{mmol} / \mathrm{L}$, respectively. There was no a statistically significant difference between the groups in terms of values of serum $\mathrm{K}^{+}$concentrations $(p=0.375)$.Serum levels of $\mathrm{Cl}^{-}$concentration were measured in the control, STZ and STZ+BQ-123 groups as $97.69 \pm 0.93 \mathrm{mmol} / \mathrm{L}, 84.61 \pm 5.38 \mathrm{mmol} / \mathrm{L}, 88.12 \pm$ $9.89 \mathrm{mmol} / \mathrm{L}$, respectively. In terms of $\mathrm{Cl}^{-}$concentration in serum levels of the groups, the values of STZ group $(p=0.0001)$ and STZ+BQ-123 group $(p=0.0001)$ were significantly lower than the values of the control group.

\section{DISCUSSION}

In our study, the blood glucose levels of STZ and STZ + BQ-123 groups measured 72 hour after STZ application were significantly higher than the values of the control group. This finding supports that, model of diabetes was successful, and $60 \mathrm{mg} / \mathrm{kg}$ dose of STZ was sufficient. In the rats that diabetes was formed after administration of STZ, during the test, for a period of 40 days, polyphagia, polydipsia, polyuria, and hyperglycemia was observed. These findings observed in diabetic rats were consistent with the clinical signs of diabetes.

Hypoleptinemia accompanies to hyperglycemia observing due to reduced insulin secretion which occurs due to the destruction of the pancreas with the effect of STZ in this model $(27,28)$. Previous studies demonstrate that, serum Leptin levels decreased in diabetes (27, 29). Studies in STZ-diabetic rats have indicated that the levels of serum Leptin and Leptin mRNA noticeably diminished (28). The levels of plasma Leptin also decreased in Type II DM patients (30) and in Type I DM patients (31). In our study, although Leptin levels in STZ group were lower than the control group, this was not statistically significant $(p=$ 
0.055). Despite the decrease in Leptin levels in diabetic groups, the reason that we did not find significantly difference may be related with STZ dose and duration.

ET-1 biosynthesis increases in diabetes, and therefore this peptide causes vascular complications. There are some studies that have shown an increase in ET-1 levels in diabetes. For example, in a study conducted by Makino and Kamatoin STZ-diabetic rats, as well as the formation of hyperglycemia, ET-1 levels were found increased significantly in STZ-diabetic rats (9).

There are some studies evaluating the relationship between Leptin and ET-1, on different systems and diseases. For example, in a study conducted by Xiong et al., it has been found that, ET-1 stimulated the production of Leptin adipocytes cultures with $\mathrm{ET}_{\mathrm{A}} \mathrm{R}(18)$. Also in another study; Quehenberger et al. found that Leptin induced ET-1 in endothelial cells (23).This data also suggest that, due to the relationship between Leptin and ET-1 levels, increased levels of ET-1 levels in diabetes may affect plasma Leptin levels. In the light of these data, even the decrease in Leptin levels in STZ group was not statistically significant; the levels of Leptin in BQ-123 decreased more. If so, it may be said that, $\mathrm{ET}_{\mathrm{A}} \mathrm{R}$ antagonist BQ-123 reduced the levels of ET which increased in diabetes. However, a longer duration of diabetes, administration time of BQ-123 can provide a meaningful detection of reduction in the levels of Leptin. The topic may be evaluated better with new studies with different doses and times.

$\mathrm{DM}$ is a chronic metabolic disorder and at the same time as an increased oxidative stress situation (32). Oxidative stress acts as a leading factor in DM and its complications $(33,34)$. Several studies inform that free radicals and reactive oxygen species increased in DM rats and patients (34-38). Lipid peroxidation occurring due to free oxygen radicals is one of the most important causes of cell damage. Lipid peroxidation is defined as a chemical event initiated by free radicals and contains the oxidation of unsaturated fatty acids of membrane structure 
(Turk et al., 2002). TBARS, produced endogenously in the body, is an important indicator of lipid peroxidation (39)and the studies indicate that tissue and plasma TBARS levels increased in diabetes. In our study, in the serum of STZ-diabetic rats, TBARS levels which are an indicator of lipid peroxidation, were increased significantly compared with control group. This increase in lipid peroxidation in diabetic rats is similar to other studies on diabetic rats and humans. In a study conducted by Turk et al., a significant increase of TBARS levels in patients with Type 2 DM has been reported (40). In another study conducted by Ruberz et al., it has been detected that, plasma TBARS levels in STZ-diabetic rats were significantly higher than the control group (41). In another study conducted by Jeyashanthi et al., an increase in serum, liver and kidney tissues levels of TBARS of STZ-diabetic rats was detected (42). Our study is in line with these data.

Researchers have used various agents against DM such as melatonin (43-46). We used BQ-123 that is a selective $\mathrm{ET}_{\mathrm{A}} \mathrm{R}$ antagonist and decreases ET-1 levels in serum (47). Although the effect of BQ-123 on TBARS levels was investigated, we did not find any study about how BQ-123 affects the increased levels of TBARS in diabetes. However, in renal ischemia and reperfusion injury, BQ-123 has as the effects of antioxidant, decreased the increased levels of TBARS (48). In another study conducted by Lund et al., it has been determined that, BQ-123 reduced cardiac TBARS levels (49). BQ-123 as an $\mathrm{ET}_{\mathrm{A}} \mathrm{R}$ antagonist inhibited the formation of lipid and protein oxidation products (50). Our results are in line with these studies. In the group treated with BQ-123, levels of TBARS showed a significant decrease compared with STZ group. In our study, it can be said that, BQ-123 has a positive effect by reducing the increased levels of TBARS in diabetes.

It has been reported that there is a significant protein oxidation caused by oxidative damage in diabetic patients (22) and diabetic rats (51). In our study, there was no significant difference between the groups in terms of serum PC levels. To keep longer duration of 
diabetes and examination on tissue samples may help to show the change in the levels of PC. In our study, due to checking only serum PC levels, in 40-day period, protein damage may not be reflected in the serum levels.

NO, was produced enzymatically by nitric oxide synthetase (NOS) from L-arginine (52). It has been reported that, in diabetes, bioactivity of NO, basal NO production and Larginine which is a NOS substrate decreased, and some researchers indicate that, in diabetes, NO production has been damaged due to decrease in the plasma levels of L-arginine (53).

Decreased levels of NO, contributes the vascular damage, by facilitating interactions of platelet-vascular wall and causing adhesion of circulating monocytes to endothelial surface (54). Therefore, it is important to keep the NO levels in the physiological limits. In our study, in terms of NO levels, there is significant difference between the values of control and STZ groups. A significant reduction in NO levels occurred in diabetic rats. The studies indicate that, NO levels decrease in diabetes. In another study conducted by Zhao et al., it has been determined that, expression of eNOS decreased in the aortas of STZ-diabetic rats (55).In the study conducted by Tessari et al. on diabetic patients, it has been reported that, concentrations of NO significantly decreased in the blood of diabetic patients (56). Our study is in line with these data. In our study, NO levels of rats in STZ and STZ + BQ-123 group decreased significantly compared to control rats, and the effect of BQ-123 which increases the level of NO was not detected.

$\mathrm{Na}^{+} / \mathrm{K}^{+}$-ATPase ionic pump has an important role for providing low $\mathrm{Na}^{+}$and high $\mathrm{K}^{+}$in the cell and maintaining the cell hemostasis (57). Deterioration of $\mathrm{Na}^{+} / \mathrm{K}^{+}$-ATPase enzyme activity in diabetes, leads disrupting in the ion balance and decrease of $\mathrm{K}^{+}$levels in the cell. In diabetes, due to $\mathrm{K}^{+}$ions shift towards the extracellular fluid from inside of the cell, increase of $\mathrm{K}^{+}$ions in extracellular fluid is expected. The reason for shifting of $\mathrm{K}^{+}$ions towards the extracellular fluid is insulin deficiency or resistance seen in diabetes (58). In our study, 
although it was not statistically significant, serum $\mathrm{K}^{+}$concentration levels in diabetic rats were significantly higher than control. Serum $\mathrm{Na}^{+}$concentration levels were significantly lower in the diabetic rats than control. $\mathrm{Cl}^{-}$concentration levels in serum were lower in diabetic rats than in the control group. Especially, $\mathrm{Cl}^{-}$is involved in the provision of osmotic pressure in the in plasma and intracellular liquid. Therefore, it is important to balance the levels of $\mathrm{Cl}^{-}$ in diabetes. Some studies supported that the defect of $\mathrm{Na}^{+} / \mathrm{K}^{+}$-ATPase activity in experimental diabetes lead to the active transport of cations play an important role in chronic diabetic complications such as neuropathy, nephropathy, and retinopathy. Reduced $\mathrm{Na}^{+} / \mathrm{K}^{+}$-ATPase activity of red blood cell membrane is considered especially as a strong marker for diabetic neuropathy (59). In the study conducted by Raccah et al., on a case of type 1 diabetes, decrease in $\mathrm{Na}^{+} / \mathrm{K}^{+}$-ATPase activity of red blood cell membrane was associated with the formation of peripheral neuropathy (60). Therefore, to control and balance $\mathrm{Na}^{+}$and $\mathrm{K}^{+}$ions is important in diabetes.

The results of this study demonstrate that, Leptin levels in STZ-diabetic rats, decrease but it is not statistically significant. BQ-123 treatment reduced more Leptin levels in diabetes, although it is not statistically significant. This result may be related to the administration time and dose of BQ-123. In the STZ-induced diabetes model, there was no statistically significant difference in levels of $\mathrm{PC}, \mathrm{K}^{+}$, but $\mathrm{Na}^{+}$and $\mathrm{Cl}^{-}$levels decreased significantly. BQ-123 treatment did not have any effect on this decrease. It is known that, in diabetes, oxidative damage increases and a marked increase in the level of TBARS occurred which an important indicator of oxidative damage is. In the group treated with BQ-123, BQ-123 had a BQ-123 by causing significantly decrease in TBARS levels of the rats. In experimental diabetes, the effects of an $\mathrm{ET}_{\mathrm{A}} \mathrm{R}$ antagonist, BQ-123 and its possible relationship with Leptin are needed to put forward a more precise manner with new studies with different doses and application times. Different $\mathrm{ET}_{\mathrm{A}} \mathrm{R}$ antagonists can be applied in this context. It is obvious that, very 
complex relationships between autocrine and paracrine factors and their interactions in changing pathophysiological conditions is a topic which needs more investigations. Also, contributions of these changing to homeostasis in pathophysiological conditions are a topic worth exploring and investigating but it is quite complicated.

\section{ACKNOWLEDGEMENT}

This research was supported and approved by The Scientific Research Fund of Gaziosmanpasa University (Project no: 2010/95).

\section{AUTHORS' NOTE}

The authors had no conflicts of interest to declare in relation to this article. 


\section{REFERENCES}

1. Ashraf JM, Arfat MY, Arif Z, Ahmad J, Moinuddin, Alam K. A clinical correlation of anti-DNA-AGE autoantibodies in type 2 diabetes mellitus with disease duration. Cell Immunol 2015; 293: 74-9.

2. Gispen WH, Biessels GJ. Cognition and synaptic plasticity in diabetes mellitus. Trends Neurosci 2000; 23: 542-9.

3. Sperling MA. Diabetes mellitus in children. Philadelphia: WB Saunders campany; 2004: 1947-72.

4. Herr RR, Eble TE, Bergy ME, Jahnke HK. Isolation and characterization of streptozotocin. Antibiotics Annual. 1959-1960. New York: Antibiotica; 1960: 236-40.

5. Tamirisa P, Frishman WH, Kumar A. Endothelin and endothelin antagonism: roles in cardiovascular health and disease. Am Heart J 1995; 130: 601-10.

6. Stevenson LW, Fonarow GC. Endothelin and the vascular choir in heart failure. J Am Coll Cardiol. 1992; 20: 854-7.

7. Inoue A, Yanagisawa M, Kimura S, Kasuya Y, Miyauchi T, Goto K, et al. The human endothelin family: three structurally and pharmacologically distinct isopeptides predicted by three separate genes. Proc Natl Acad Sci U S A 1989; 86: 2863-7.

8. Economos D, Crabtree DA. Analysis of strength and endurance in fast twitch skeletal muscle after an acute in vitro exposure to an anabolic steroid. J Sports Med Phys Fitness 1991; 31: 433-8.

9. Makino A, Kamata K. Elevated plasma endothelin-1 level in streptozotocininduced diabetic rats and responsiveness of the mesenteric arterial bed to endothelin-1. Br J Pharmacol 1998; 123: 1065-72. 
10. Yang L, Fan J, Mi X, Liu X, Xu G. [Protective effect of angiotensin II receptor blockage on rats with experimental diabetes nephropathy in early stage]. Sichuan Da Xue Xue Bao Yi Xue Ban 2003; 34: 317-9.

11. Sliwinska-Mosson M, Sciskalska M, Karczewska-Gorska P, Milnerowicz H. The effect of endothelin-1 on pancreatic diseases in patients who smoke. Adv Clin Exp Med 2013; 22: 745-52.

12. Caro JF, Sinha MK, Kolaczynski JW, Zhang PL, Considine RV. Leptin: the tale of an obesity gene. Diabetes. 1996; 45: 1455-62.

13. Wilding J, Widdowson P, Williams G. Neurobiology. Br Med Bull 1997; 53: 286306.

14. Leroy P, Dessolin S, Villageois P, Moon BC, Friedman JM, Ailhaud G, et al. Expression of ob gene in adipose cells. Regulation by insulin. J Biol Chem 1996; 271: $2365-8$.

15. Al-Suhaimi EA, Shehzad A. Leptin, resistin and visfatin: the missing link between endocrine metabolic disorders and immunity. Eur J Med Res 2013; 18: 12.

16. German JP, Wisse BE, Thaler JP, Oh IS, Sarruf DA, Ogimoto K, et al. Leptin deficiency causes insulin resistance induced by uncontrolled diabetes. Diabetes. 2010; 59: 1626-34.

17. Chinookoswong N, Wang JL, Shi ZQ. Leptin restores euglycemia and normalizes glucose turnover in insulin-deficient diabetes in the rat. Diabetes. 1999; 48: 148792.

18. Xiong Y, Tanaka H, Richardson JA, Williams SC, Slaughter CA, Nakamura M, et al. Endothelin-1 stimulates leptin production in adipocytes. J Biol Chem 2001; 276: $28471-7$. 
19. Juan CC, Chuang TY, Lien CC, Lin YJ, Huang SW, Kwok CF, et al. Leptin increases endothelin type A receptor levels in vascular smooth muscle cells. Am J Physiol Endocrinol Metab 2008; 294: E481-7.

20. Quehenberger P, Exner M, Sunder-Plassmann R, Ruzicka K, Bieglmayer C, Endler G, et al. Leptin induces endothelin-1 in endothelial cells in vitro. Circulation 2002; 90: 711-8.

21. S. AHC. Ratlarda diyabet öncesi ve sonrası oksidan-antioksidan durum. Firat University Vet J Health Sci 2010; 24: 05-10.

22. Ozgun G.S. ES, Sut N. . The Effects of L-Carnitine on Protein Oxidation of Streptozotocin-Induced Diabetic Rats. Turk J Biochem 2010; 35: 183-9.

23. Considine RV, Sinha MK, Heiman ML, Kriauciunas A, Stephens TW, Nyce MR, et al. Serum immunoreactive-leptin concentrations in normal-weight and obese humans. N Engl J Med 1996; 334: 292-5.

24. Mihara M, Uchiyama M. Determination of malonaldehyde precursor in tissues by thiobarbituric acid test. Anal Biochem 1978; 86: 271-8.

25. Levine RL, Garland D, Oliver CN, Amici A, Climent I, Lenz AG, et al. Determination of carbonyl content in oxidatively modified proteins. Methods Enzymol 1990; 186: 464-78.

26. Cortas NK, Wakid NW. Determination of inorganic nitrate in serum and urine by a kinetic cadmium-reduction method. Clin Chem 1990; 36: 1440-3.

27. Havel PJ, Uriu-Hare JY, Liu T, Stanhope KL, Stern JS, Keen CL, et al. Marked and rapid decreases of circulating leptin in streptozotocin diabetic rats: reversal by insulin. Am J Physiol 1998; 274: R1482-91. 
28. Sivitz WI, Walsh S, Morgan D, Donohoue P, Haynes W, Leibel RL. Plasma leptin in diabetic and insulin-treated diabetic and normal rats. Metabolism 1998; 47: 584-91.

29. Zhang Y, Proenca R, Maffei M, Barone M, Leopold L, Friedman JM. Positional cloning of the mouse obese gene and its human homologue. Nature 1994; 372: 425-32.

30. Man'kovs'kyi BM, Urbanovych AM. [The blood leptin and the activity of the system inflammatory response in patients with diabetes mellitus type 2 with different body weight and disease duration]. Fiziol Zh 2014; 60: 56-60.

31. Musil F, Blaha V, Ticha A, Hyspler R, Haluzik M, Lesna J, et al. Effects of body weight reduction on plasma leptin and adiponectin/leptin ratio in obese patients with type 1 diabetes mellitus. Physiol Res 2014; 64: 221-8.

32. Atalay M, Laaksonen DE. Diabetes, oxidative stress and physical exercise. J Sports Sci Med 2002; 1: 1-14.

33. Babizhayev MA, Strokov IA, Nosikov VV, Savel'yeva EL, Sitnikov VF, Yegor EY, et al. The Role of Oxidative Stress in Diabetic Neuropathy: Generation of Free Radical Species in the Glycation Reaction and Gene Polymorphisms Encoding Antioxidant Enzymes to Genetic Susceptibility to Diabetic Neuropathy in Population of Type I Diabetic Patients. Cell Biochem Biophys 2014.

34. Sultan MT, Butt MS, Karim R, Iqbal SZ, Ahmad S, Zia-Ul-Haq M, et al. Effect of Nigella sativa fixed and essential oils on antioxidant status, hepatic enzymes, and immunity in streptozotocin induced diabetes mellitus. BMC Complement Altern Med 2014; 14: 193.

35. Hayakawa M, Kuzuya F. [Free radicals and diabetes mellitus]. Nihon Ronen Igakkai Zasshi 1990; 27: 149-54. 
36. Pandey KB, Mishra N, Rizvi SI. Protein oxidation biomarkers in plasma of type 2 diabetic patients. Clin Biochem 2010; 43: 508-11.

37. Belch JJ, Mackay IR, Hill A, Jennings P, McCollum P. Oxidative stress is present in atherosclerotic peripheral arterial disease and further increased by diabetes mellitus. Int Angiol 1995; 14: 385-8.

38. Aghamohammadi V, Gargari BP, Aliasgharzadeh A. Effect of folic acid supplementation on homocysteine, serum total antioxidant capacity, and malondialdehyde in patients with type 2 diabetes mellitus. J Am Coll Nutr 2011; 30: $210-5$.

39. Gulen S, Dincer S. Effects of leptin on oxidative stress in healthy and Streptozotocin-induced diabetic rats. Moll Cell Biochem 2007; 302: 59-65.

40. Turk HM, Sevinc A, Camci C, Cigli A, Buyukberber S, Savli H, et al. Plasma lipid peroxidation products and antioxidant enzyme activities in patients with type 2 diabetes mellitus. Acta Diabetol 2002; 39: 117-22.

41. Ruperez FJ, Garcia-Martinez D, Baena B, Maeso N, Cifuentes A, Barbas C, et al. Evolution of oxidative stress parameters and response to oral vitamins $\mathrm{E}$ and $\mathrm{C}$ in streptozotocin-induced diabetic rats. J Pharm Pharmacol 2008; 60: 871-8.

42. Jeyashanthi N, Ashok V. Anti-Oxidative Effect of Cassia auriculata on Streptozotocin Induced Diabetic Rats. Indian J Clin Biochem 2010; 25: 429-34.

43. Fadillioglu E, Kurcer Z, Parlakpinar H, Iraz M, Gursul C. Melatonin treatment against remote organ injury induced by renal ischemia reperfusion injury in diabetes mellitus. Arch Pharm Res 2008; 31: 705-12.

44. Kurcer Z, Parlakpinar H, Vardi N, Tasdemir S, Iraz M, Fadillioglu E, et al. Protective effects of chronic melatonin treatment against renal 
ischemia/reperfusion injury in streptozotocin-induced diabetic rats. Exp Clin Endocrinol Diabetes 2007; 115: 365-71.

45. Baydas G, Canatan H, Turkoglu A. Comparative analysis of the protective effects of melatonin and vitamin E on streptozocin-induced diabetes mellitus. J Pineal Res 2002; 32: 225-30.

46. Sailaja Devi MM, Suresh Y, Das. Preservation of the antioxidant status in chemically-induced diabetes mellitus by melatonin. J Pineal Res 2000; 29: 10815.

47. Feger GI, Schilling L, Ehrenreich H, Wahl M. Endothelin-induced contraction and relaxation of rat isolated basilar artery: effect of BQ-123. J Cereb Blood Flow Metab 1994; 14: 845-52.

48. Erdogan H, Fadillioglu E, Emre MH. Protection from renal ischemia reperfusion injury by an endothelin-A receptor antagonist BQ-123 in relation to nitric oxide production. Toxicology 2006; 228: 219-28.

49. Lund AK, Peterson SL, Timmins GS, Walker MK. Endothelin-1-mediated increase in reactive oxygen species and NADPH Oxidase activity in hearts of aryl hydrocarbon receptor (AhR) null mice. Toxicol Sci 2005; 88: 265-73.

50. Buyukgebiz O, Aktan AO, Haklar G, Yalcin AS, Yegen C, Yalin R, et al. BQ123, a specific endothelin (ETA) receptor antagonist, prevents ischemiareperfusion injury in kidney transplantation. Transpl Int 1996; 9: 201-7.

51. Kayali R, Telci A, Cakatay U, Karaca C, Akcay T, Sivas A, et al. Oxidative protein damage parameters in plasma in chronic experimental diabetes in rats. Eur J Med Res 2003; 8: 307-12. 
52. Amin KA, Awad EM, Nagy MA. Effects of panax quinquefolium on streptozotocin-induced diabetic rats: role of C-peptide, nitric oxide and oxidative stress. Int J Clin Exp Med 2011; 4: 136-47.

53. Kino M, Yamato T, Aomine M. Simultaneous measurement of nitric oxide, blood glucose, and monoamines in the hippocampus of diabetic rat: an in vivo microdialysis study. Neurochem Int 2004; 44: 65-73.

54. Kocaturk PA. [The pathogenesis of diabetes and the role of nitric oxide complications] Nitrik oksitin diyabet patogenezi ve komplikasyonlarındaki rolü. Ankara Üniversitesi Tıp Fakültesi Mecmuası 1996; 49: 4.

55. Zhao ZW, Cai W, Lin YL, Lin QF, Jiang Q, Lin Z, et al. Ameliorative effect of astaxanthin on endothelial dysfunction in streptozotocin-induced diabetes in male rats. Arzneimittelforschung 2011; 61: 239-46.

56. Tessari P, Cecchet D, Cosma A, Vettore M, Coracina A, Millioni R, et al. Nitric oxide synthesis is reduced in subjects with type 2 diabetes and nephropathy. Diabetes 2010; 59: 2152-9.

57. Djemli-Shipkolye A, Gallice P, Coste T, Jannot MF, Tsimaratos M, Raccah D, et al. The effects ex vivo and in vitro of insulin and C-peptide on $\mathrm{Na} / \mathrm{K}$ adenosine triphosphatase activity in red blood cell membranes of type 1 diabetic patients. Metabolism 2000; 49: 868-72.

58. Ramesh B, Pugalendi KV. Influence of umbelliferone on membrane-bound ATPases in streptozotocin-induced diabetic rats. Pharmacol Rep 2007; 59: 33948.

59. Kiziltunc A, Akcay F, Polat F, Kuskay S, Sahin YN. Reduced lecithin: cholesterol acyltransferase (LCAT) and $\mathrm{Na}+\mathrm{K}+$, ATPase activity in diabetic patients. Clin Biochem 1997; 30: 177-82. 
60. Raccah D, Fabreguetts C, Azulay JP, Vague P. Erythrocyte Na(+)-K(+)-ATPase activity, metabolic control, and neuropathy in IDDM patients. Diabetes Care 1996; 19: 564-8. 
Table 1: Plasma levels of Leptin $(\mathrm{ng} / \mathrm{ml})$ and serum levels of TBARS ( $\mathrm{nmol} / \mathrm{mL})$, PC (nmol/mL), NO (nmol/mL).

\begin{tabular}{lllll}
\hline Groups & Leptin $(\mathrm{ng} / \mathrm{mL})$ & TBARS $(\mathrm{nmol} / \mathrm{mL})$ & $\mathrm{PC}(\mathrm{nmol} / \mathrm{mL})$ & $\mathrm{NO}(\mathrm{nmol} / \mathrm{mL})$ \\
\hline Control & $0.93 \pm 0.58$ & $1.55 \pm 0.16$ & $903.88 \pm 280.45$ & $46.32 \pm 3.85$ \\
STZ & $0.58 \pm 0.35$ & $1.97 \pm 0.24$ & $930.50 \pm 252.09$ & $38.52 \pm 2.26$ \\
STZ+BQ123 & $0.38 \pm 0.29$ & $1.65 \pm 0.10$ & $1040.50 \pm 400.41$ & $37.48 \pm 4.88$ \\
\hline
\end{tabular}




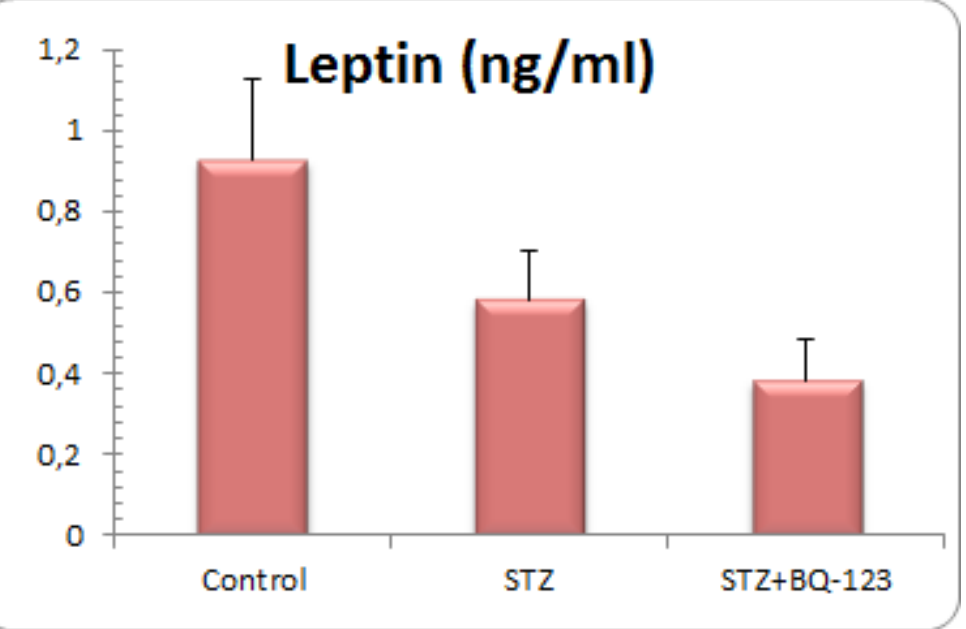

Fig 1: Leptin levels in the experimental groups $(\mathrm{ng} / \mathrm{ml})$ : There is no significant difference between the groups.

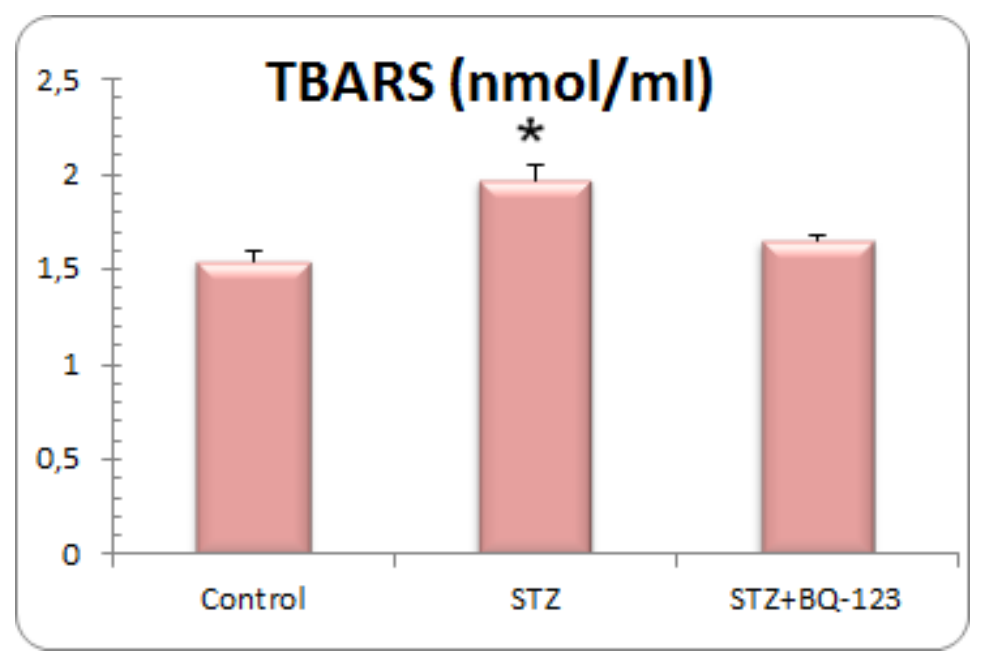

Fig 2: TBARS levels in the experimental groups. TBARS levels of STZ group were significantly higher than the control $\left({ }^{*} p=0.0001\right)$ and STZ+BQ-123 $(* p=0.0004)$ groups. 


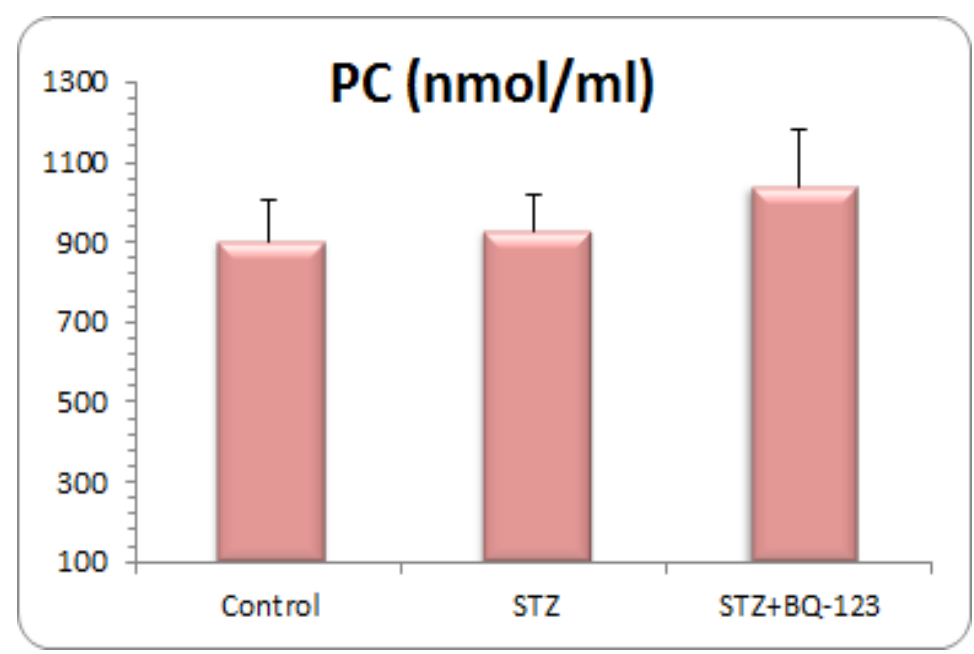

Fig 3: PC levels in the experimental groups. There is no significant difference between the groups.

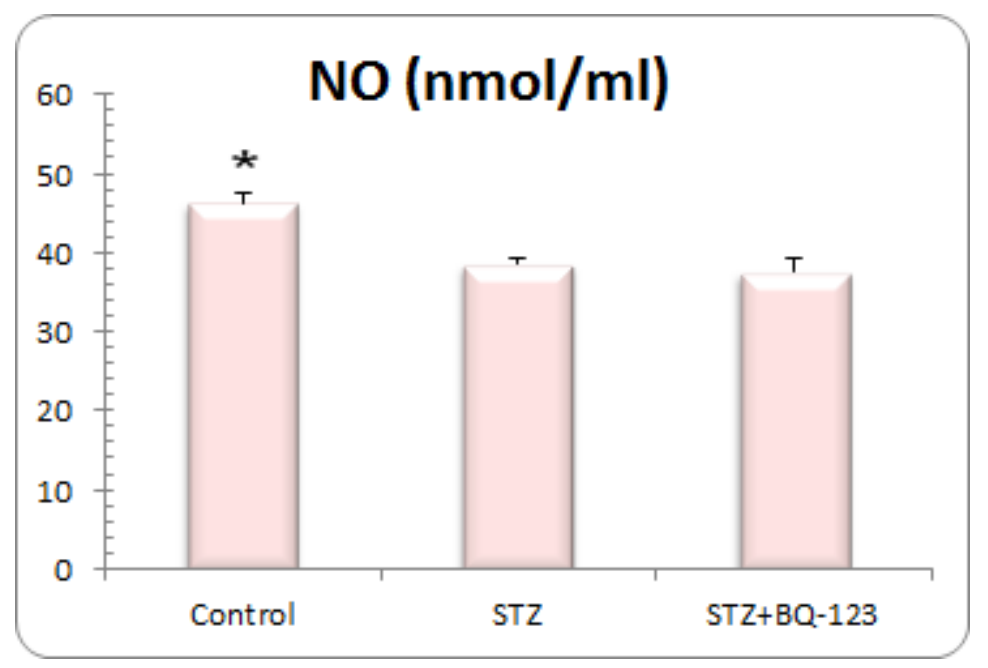

Fig 4: NO levels in the experimental groups. The other groups were found to be significantly lower than the control group $(* p=0.0001)$. 